\title{
Zagadnienia Rodzajów Literackich. Początki
}

Nie ma tego złego, co by na dobre nie wyszło.

Tuż po wojnie, gdy w 1945 r. w nowo powstałym Uniwersytecie Łódzkim powołano Katedrę Teorii Literatury, jej kierownik, Stefania Skwarczyńska, zainicjowała prace nad stworzeniem Stownika rodzajów literackich ${ }^{1}$ i dla inicjatywy tej znalazła oficjalne poparcie wśród władz i członków reaktywowanego właśnie Łódzkiego Towarzystwa Naukowego. W 1947 r. ukonstytuowano w nim Komisję Stownika i jego redakcję; przygotowany i przedstawiony na posiedzeniu Wydziału I ŁTN został też Projekt Stownika (Skwarczyńska 1947: 4), a w $1951 \mathrm{r}$. powstał kolejny dokument świadczący o zaawansowaniu prac przygotowawczych, mianowicie zbiór informacji i wskazówek dla autorów haseł ${ }^{2}$. „Słownik został opracowany w całości i w szczegółach jako zadanie do wypełnienia” w ramach Planu Sześcioletniego (Ostrowski 1992: 80), co — jak można się domyślać — miało ułatwić realizację tego wyjątkowego i bardzo kosztownego zamierzenia. Do tego czasu na zamówienie redakcji napisano już 30 artykułów oraz zgromadzono ok. 3500, zachowanych do dziś, „fiszek z hasłami gatunkowymi i paragatunkowymi” (Gazda 2006: IX) i choć „mają one - jak twierdzi Gazda — charakter nader impresyjny i mało systematyczny" (Gazda 2006: XII), stanowią nadal świadectwo wielkiej pracy i nie mniejszego zaangażowania osób uczestniczących w przygotowaniu Stownika. Dowodzą też faktu, że był on pomyślany jako dzieło totalne, obejmujące całą literaturę światową, wraz z twórczością ludową oraz formami literatury użytkowej.

„Później - piszą autorzy wspomnień - zaczęły się trudności, wynikające z ówczesnych uwarunkowań politycznych i personalnych" (Ostrowski 1992: 80). Po pierwsze, w maju 1952 r. Skwarczyńskiej odebrano katedrę, której działalność zawieszono. Po wtóre, pierwsza w Polsce uniwersytecka katedra teorii literatury już wcześniej budziła niechęć części pracowników powstałego niedawno Instytutu Badań Literackich PAN, przede wszystkim, jak uważała

1 Dzieje tego przedsięwzięcia opisali: Grzegorz Gazda (1992: 86-95), Witold Ostrowski (1992: 78-84, Stefania Skwarczyńska (1985: 281-316).

2 Ostrowski powołuje się na podpisany przez Skwarczyńską maszynopis pt. Informacje i wskazówki dla redaktorów i autorów „Stownika rodzajów literackich” (Ostrowski 1992: 78), który to dokument znajduje się obecnie w archiwum G. Gazdy (Gazda 2006: IX). 
sama Skwarczyńska — Marii Renaty Mayenowej i Marii Dłuskiej, „śmiertelnie obrażonych, że pozwoliłam sobie nie liczyć się z ich monopolem na teorię literatury i wersyfikację"”. Kiedy więc na początku 1957 r., szukając poparcia dla pomysłu wydania zeszytu próbnego Stownika rodzajów literackich, do IBL na specjalną konferencję udała się grupa łódzkich redaktorów ze Skwarczyńską na czele, okazało się, że zamiast z aprobatą spotkała się z milczącym sprzeciwem. Wydawało się, że na skutek tej niechęci ambitny, ale realnie ukształtowany projekt czeka klęska.

Rozczarowany tym faktem był też dr Stanisław Łukasik, romanista, wówczas już autor licznych artykułów do Stownika. Nie otrzymawszy ani gwarancji publikacji, ani tym samym uzgodnionych honorariów za druk, pozwał do sądu instytucję, z którą zawierał umowę, czyli ŁTN. By załagodzić spór, a przede wszystkim, by uratować tak już zaawansowane prace całego zespołu i nie dopuścić do przywłaszczenia samego pomysłu czy choćby części materiałów ${ }^{4}$, na przełomie stycznia i lutego 1957 r. powzięto zamiar, by zamiast Stownika wydawać półrocznik, w którym publikowane byłyby Materiaty do Stownika oraz artykuły o tematyce genologicznej, recenzje i przeglądy związanych z genologią publikacji polskich i zagranicznych.

$\mathrm{Z}$ formalnego punktu widzenia ta nowa inicjatywa była dziełem ŁTN. To jego ówczesny sekretarz generalny, prof. Jan Dylik sygnował niektóre oficjalne pisma związane z powołaniem do życia owego periodyku. Faktycznie jednak za instytucją stali dawni członkowie Komisji Stownika i jego redaktorzy. Wydaje się oczywiste i niewątpliwe, że decyzję o przekształceniu wydawnictwa zwartego w czasopismo musiała podjąć S. Skwarczyńska. Tak twierdzi Ostrowski: „charakter i tytuł [nowego wydawnictwa ciągłego] zostały obmyślone przez prof. Skwarczyńską w porozumieniu z zarządem ŁTN” (Ostrowski 1992: 82). Z jej notatek i korespondencji z Janem Trzynadlowskim z lutego 1957 r. wynika jednak, że zamiarem Profesor było niesystematyczne wydawanie samych Materiatów do Stownika, a to Trzynadlowski zaproponował stworzenie półrocznika („bez rygorów zwykłego czasopisma”, ale jednak ukazującego się systematycznie), przedstawił projekt jego zawartości i układ treści ${ }^{6}$, zasugerował, by nazwa nie brzmiała Materiaty..., ale „Zagadnienia teorii literatury, a w podtytule Pótrocznik poświęcony problematyce teoretycznoliterackiej (lub coś w tym rodzaju)" oraz podsunął

3 W datowanym na 23 marca 1957 r. liście do Juliusza Kleinera pisze o nich: „, damy [...] Mayenowa, Dłuska”. Oryginały wszystkich listów, na które powołuję się i które cytuję, pochodzą z 1957 r. a dostępne są w Bibliotece Uniwersytetu Łódzkiego w Sekcji Dokumentów Życia Społecznego. O ile w tekście nie podaję datowania listów, w przypisach stosuję zapis: nazwisko autora, data dzienna i miesięczna (gdy adresatką listu jest Stefania Skwarczyńska) lub: Skwarczyńska do..., data dzienna i miesięczna.

4 „W Materiatach do Stownika chcielibyśmy na pierwszy ogień dać tę część (mniej więcej), którą zaprojektowaliśmy z okazji konferencji w sprawie Słownika w IBL-u. Boimy się, że ten materiał zostanie «oskubany»" (Skwarczyńska do J. Kleinera, bd [marzec]).

5 „Przede wszystkim uważam za rzecz wagi niemałej — pisze w liście z 11 lutego 1957 r. — nadanie tej publikacji charakteru continuum w tym celu, aby redakcji zapewnić stałe miejsce w planie wydawniczym, a równocześnie pozyskać stale rozszerzający się krąg czytelników. Chodzi o to, aby było wiadome, że rzecz stale wychodzi i nie ma charakteru wydawniczej efemerydy. Moim zdaniem najlepszą formą byłaby postać półrocznika (podobnie jak językoznawcze »Onomastica «). Półrocznik numerowany ciągle w sposób Rok I z. 1, Rok I z. 2, Rok II z. 1, Rok II z. 2 itd. ma już charakter czasopisma, a nie wymaga takich rygorów formalnych i administracyjnych jak czasopismo sensu stricto" (Trzynadlowski, 11 lutego).

6 „Jak, moim zdaniem, powinien wyglądać wewnętrzny układ zeszytu? Winien on zawierać nast. działy: 1. Rozprawy, 2. Materiały do słownika, 3. Dział recenzyjno-sprawozdawczy, 4. Korespondencja i polemika.

Ponieważ integralną częścią numeru mają być materiały słownikowe, dział ten winien być objętościowo najobszerniejszy (ok. 6 arkuszy). Reszta zawartości winna być podzielona mniej więcej tak, aby na dział pierwszy przypadało ok. 2 arkuszy i tyle samo na działy 3 i 4 łącznie. Jest to oczywiście podział czysto szacunkowy [...]" (Trzynadlowski, 11 lutego). 
pomysł, by wydawnictwo to miało charakter międzynarodowy (Trzynadlowski, 11 lutego). Domniemanie co do autorstwa owego konceptu potwierdzają słowa samej Skwarczyńskiej z datowanego na 23 marca 1957 r. listu do Kazimierza Budzyka: „wbrew pozorom, nie ja wymyśliłam to pismo; ale też kiedyś o tym więcej”. Tak więc Skwarczyńska zaakceptowała propozycję i z niemałą energią włączyła się w jej uściślanie i urzeczywistnianie, widać jednak, że większość prac koncepcyjnych wykonał J. Trzynadlowski, wówczas już pracownik Uniwersytetu Wrocławskiego i redaktor w Wydawnictwie Zakładu Narodowego im. Ossolińskich we Wrocławiu (co bardzo pomogło w rozwiązywaniu problemów formalnych, związanych $\mathrm{z}$ organizacją nowego periodyku).

$\mathrm{Na}$ początku marca powołano trzyosobową redakcję w osobach Stefanii Skwarczyńskiej, Jana Trzynadlowskiego i Witolda Ostrowskiego. Jednocześnie, już w drugiej połowie lutego i w marcu, Skwarczyńska wysłała listy do blisko trzydziestu osób, uznanych przez nią za „cały nasz szczytowy świat filologiczny” (Skwarczyńska do J. Kleinera, 23 marca), prosząc je przede wszystkim o udział w radzie redakcyjnej, ale również o wyrażenie opinii o projektowanym czasopiśmie. Prowadziła też korespondencję zagraniczną, zapraszała do współpracy literaturoznawców m.in. z Anglii, Belgii, Czechosłowacji, Francji, Jugosławii, Niemiec, Związku Radzieckiego, dążąc do zrealizowania idei umiędzynarodowienia przyszłego półrocznika. Niebawem, bo w połowie kwietnia gotowa była też przygotowana przez Trzynadlowskiego ankieta dotycząca pisma. Zawierała krótką informację o jego celu, układzie treści i, co ważne, pytanie o tytuł. Rozesłana została — już jako pismo sygnowane przez Ossolineum, przyszłego wydawcę - do niemal tych samych osób, z którymi wcześniej korespondowała Skwarczyńska. Pożytek z owej ankiety był jednak taki, że teraz odpowiedzi stanowiły oficjalne głosy w sprawie owego nowatorskiego zamierzenia.

Wprawdzie nie wszyscy odpisywali na listy (w tej małej grupie znalazł się m. in. Kazimierz Wyka, co bardzo niepokoiło Skwarczyńską, liczyła bowiem na jego poparcie i w liście z 23 marca prosiła nawet J. Kleinera o wstawiennictwo w tej sprawie ${ }^{7}$ ), ale wielu zaaprobowało pomysł i deklarowało pomoc oraz współpracę redakcyjną i autorską. Dwukrotnie z wielkim aplauzem wypowiedział się Kazimierz Budzyk, mimo że jednocześnie toczył ze Skwarczyńską osobisty spór ${ }^{8} .16$ marca pisał: „Będzie to pierwsza próba wyjścia polskiej nauki o literaturze poza rodzime opłotki, o których zresztą po niedawnej «wycieczce» do ZSRR teraz jestem o wiele lepszego mniemania niż dawniej”. I na początku kwietnia: „Obecna sytuacja jest taka, że jedyny zorganizowany ośrodek teoretycznoliteracki ma charakter ultraformalistczny [...]. Wasze pismo ma szansę stać się naukową przeciwwagą dla owego środowiska formalistów” ". A Stanisław Pigoń był wyraźnie ucieszony, że „wreszcie ruszy się

7 „Dotąd nie odpowiedział prof. Wyka; gdyby go kiedy Pan Profesor spotkał — i wskazał mu, że piękny by dał dowód w przezwyciężeniu monopolistycznych tendencji IBLu - gdyby się zdecydował...”.

8 Jego przyczyną było trudne dziś do wyjaśnienia nieporozumienie, związane z wypowiedzią S. Skwarczyńskiej na temat likwidacji na początku 1957 r. Katedry Teorii Literatury UŁ. Jak Budzyk wypomina Skwarczyńskiej w liście z 16 marca 1957 r., na łamach „Życia i Myśli” miała ona sugerować, że był on przeciwny istnieniu łódzkiej katedry, podczas gdy on nigdy takiego stanowiska nie reprezentował; co więcej, dodawał w oskarżycielskim tonie, mimo że słowa Skwarczyńskiej ukazały się drukiem, jego sprostowanie nie zostało opublikowane i wśród czytelników „Życia i Myśli” pozostało fałszywe wyobrażenie o jego zachowaniu w tamtej, będącej przyczyną sporu, sytuacji. Skwarczyńska próbowała zażegnać ten konflikt, ale w liście do J. Kleinera pisała z pewną złośliwością o niejednoznacznej postawie Budzyka, który „chciałby, ale mu honor nie pozwala, bo ja posądziłam go o szkodzenie mi!” (Skwarczyńska do J. Kleinera, 23 marca).

9 Budzyk ma na myśli oczywiście IBL (Budzyk, 2 kwietnia). 
z miejsca zatoru sprawa Słownika Rodzajów, od tak dawna zagwożdżona” (Pigoń, 17 marca). Rzadko przychodziły odpowiedzi zdecydowanie odmowne. Jedyną, która się zachowała, przesłała M. Dłuska ${ }^{10}$. O „grzecznej odmowie” drugiej IBL-owskiej „ultraformalistki”, M.R. Mayenowej, wiadomo natomiast z notatki Skwarczyńskiej, która miała zwyczaj nie tylko sporządzania wykazów adresatów korespondencji, ale i tworzenia przy ich nazwiskach krótkich adnotacji na temat treści wysłanych i otrzymanych listów.

Sporo osób zgłaszało jednak różnorakie wątpliwości, a nawet negowało zasadność tworzenia nowego pisma. Tadeusz Grzebieniowski, Kazimierz Żygulski i Marian Serejski zwracali uwagę na jego wtórny charakter, twierdząc, że powielałoby tematykę podejmowaną w czasopismach już istniejących i postulując, by artykuły o charakterze genologicznym i hasła do Stownika publikować w tychże. Serejski zastanawiał się też, czy genologia zainteresuje badaczy zachodnioeuropejskich (Serejski, 18 kwietnia). W podobnym duchu wypowiedział się i Pigoń, wcześniej przecież popierający tę inicjatywę wydawniczą, teraz zaś dość arbitralnie twierdzący, że nie znając dorobku literaturoznawców zachodnioeuropejskich, nie można mieć pewności, iż zaciekawią ich badania literaturoznawców polskich, a wówczas czasopismo „nie dobije się w świecie większego znaczenia” (Pigoń, 26 kwietnia). Żygulski dodatkowo wyrażał obawę, czy znajdzie się dostateczna liczba materiałów do tak wąsko pomyślanego periodyku. Stanisław Pigoń i Czesław Zgorzelski wróżyli nawet, że systematyka rodzajów literackich - choćby drobiazgowa - musi doprowadzić do rychłego wyczerpania materiału badań i szybkiej likwidacji pisma (Zgorzelski, 29 kwietnia).

Zastrzeżenia Zgorzelskiego budziła też „niewskazana” (jak ją określił) dominacja zagadnień teoretycznych nad historycznoliterackimi. W kilku przypadkach twierdzono jednak, że czasopismo powinno mieć właśnie charakter teoretycznoliteracki, ale uwzględniać musi wszystkie, nie wyłącznie genologiczne, problemy podejmowane przez współczesną teorię literatury ${ }^{11}$. Sam Trzynadlowski nie był wolny od podobnych wątpliwości. Przy końcu czerwca pisał do Skwarczyńskiej:

Uparcie nachodzi mnie myśl o nieodzowności dania wyrazu i szerszej problematyce teorii literatury, co staje mi się widoczne i przy opracowywaniu recenzji książki prof. Kleinera ${ }^{12}$. Prymat zagadnień genologicznych, zgoda, ale chyba prymat, a nie wyłączność. Obawiam się różnych niebezpieczeństw praktycznych przy wyłącznym postawieniu sprawy. Bardzo proszę wyrzec swe ostatnie słowo w tej materii. (Trzynadlowski, 24 czerwca).

10 „Dziękuję za uprzejmą propozycję udziału w Radzie Redakcyjnej oraz współpracy autorskiej w półroczniku $\gg Z$ Genologii Literackiej«. Proszę jednak nie liczyć ani na jedno, ani na drugie z mojej strony. Nie pozwoliłoby mi na to już samo obciążenie czasowe, ponadto sprawa nie jest dla mnie aktualna, gdyż biorę udział w wydawnictwie «Poetyka - zarys encyklopedyczny»." (Dłuska, 21 marca).

11 Pogląd m. in. Mieczysława Brahmera (23 marca), K. Budzyka (2 kwietnia), Juliana Krzyżanowskiego (12 marca), Henryka Markiewicza (10 kwietnia), S. Pigonia (26 kwietnia).

12 Skwarczyńska poprosiła Trzynadlowskiego o przygotowanie do pierwszego numeru pisma omówienia genologicznych poglądów J. Kleinera, sformułowanych w jego rozprawie Studia z zakresu teorii literatury. Acz Trzynadlowski polemizował długo z takim pomysłem, dowodząc, że Kleiner to teoretyk „w szerszym znaczeniu" (Trzynadlowski, 14 października), artykuł ukazał się pod tytułem Poglady Juliusza Kleinera na rodzaje literackie (Na marginesie „Studiów z zakresu teorii literatury”). 
W przeciągu miesiąca Skwarczyńska musiała to uczynić, gdyż w liście z 23 lipca Trzynadlowski wyraża radość, że Profesor rozwiała jego wątpliwości co do „szkodliwego”, bo nadmiernego zawężenia problematyki i wykluczenia w związku z tym dziedzin teorii niezwiązanych ściśle z genologią.

Niemałych kłopotów nastręczał też tytuł owego półrocznika. Na samym początku jego projektowania, 11 lutego, Trzynadlowski zaproponował "Zagadnienia teorii literatury, a w podtytule Pótrocznik poświęcony problematyce teoretycznoliterackiej”. Potem jednak konstatował: „Istotnie tytuł $Z$ zagadnień teorii literatury nie jest najszczęśliwszy” (Trzynadlowski, 3 kwietnia). Skwarczyńska zaś w listach pisanych przed końcem marca używała nazw $Z$ genologii literackiej lub Zagadnienia genologii literackiej.

Pomysł tytułu, w którym pojawiłoby się słowo „genologia” skrytykowali jednak Roman Ingarden, w kolokwialnym stylu zwracający się do adresatki: „mi się strasznie nie podoba «genologia», czyż nie ma jakiegoś polskiego wyrazu?” (Ingarden, 7 marca) oraz Mieczysław Brahmer, który (choć w późniejszej korespondencji usprawiedliwiał swój początkowy krytycyzm troską o jak najdoskonalszy kształt tytułu) twierdził z kolei, że genologia to pojęcie, które „wprowadza od razu pierwiastek erudycyjnego pedantyzmu”, zatem będzie „nie do przełknięcia” dla historyka literatury. Zaproponował, by pismo miało „raczej tytuł «symboliczny» w rodzaju przedwojennego Helikonu na Węgrzech, obecnego Diogenesa w Paryżu czy naszego Meandra, choćby np. Scaliger. Rocznik poświęcony zagadnieniom teorii literatury” (Brahmer, 20 marca). W związku z tymi głosami Skwarczyńska pisała do Kleinera: „waham się co do tytułu z racji pewnej krytyki prof. Ingardena oraz prof. Brahmera, który proponuje «symboliczną» jak np. dawny Helikon, co nie bardzo mi się podoba” (Skwarczyńska do Kleinera, 23 marca), a w datowanym na 28 marca liście do Trzynadlowskiego użyła po raz pierwszy tytułu Zagadnienia rodzajów literackich. Własne koncepty przedstawili też Marian Plezia: Litterarum genera — uzasadniając go tym, iż „przyciągnie filologów klasycznych” (Plezia, 15 kwietnia), Jerzy Schneider: Genetyka literacka. Zagadnienia i materiaty ${ }^{13}$ ) oraz Kazimierz Budzyk: „Poetyka lub jakoś podobnie” (Budzyk, 2 IV). Tytuł Zagadnienia rodzajów literackich, który pojawił się po raz pierwszy kilka tygodni wcześniej, zastosował też w połowie kwietnia Trzynadlowski we wspomnianej już ankiecie. Za datę ostatecznej decyzji przyjąć należy jednak dopiero 23 lipca 1957 r., gdy w liście do Skwarczyńskiej Trzynadlowski podsumował: „pozostańmy przy tytule (i problematyce) Zagadnienia rodzajów literackich”.

Mimo tych i wielu innych wątpliwości, nawet sporów, mimo konieczności szybkiego podejmowania trudnych decyzji oraz oporu części środowiska teoretyków literatury, w drugiej połowie 1957 r. — a więc w ciągu zaledwie kilku miesięcy od pierwszej rozmowy na temat możliwości wyjścia z impasu, w jakim za sprawą niechęci badaczy z IBL znaleźli się pomysłodawcy i redaktorzy Stownika rodzajów literackich — trwały już intensywne a jednocześnie zwykłe prace nad zawartością pierwszego numeru, gotowy był też tzw. prospekt „Zagadnień Rodzajów Literackich”. Ten druk reklamowy, przygotowany w trzech językach, rozesłany na początku 1958 r. do licznych ośrodków badań literackich i bibliotek uniwersyteckich w kraju i za granicą, łączył aspekt handlowy z zaproszeniem do współpracy. I zapowiadał pierwszy numer nowego periodyku, który ukazał się nieco później, ale jeszcze w 1958 roku.

13 Propozycja Schneidera znana jest z jej omówienia w liście Trzynadlowskiego do Skwarczyńskiej, w którym autor lapidarnie komentował: „określenie »genetyka « niewłaściwe, bo wzięte żywcem z biologii chyba” (Trzynadlowski, 18 kwietnia). 
Od tamtej pory do dziś, nieprzerwanie przez sześćdziesiąt jeden lat, ZRL ukazują się regularnie, publikując - zgodnie z zamiarem twórców - Materiaty do Stownika oraz rozprawy, przeglądy i recenzje, w tym, od początku, niezmienionym układzie. Natomiast ideę Stownika rodzajów literackich zrealizował pół wieku po jej narodzinach, bo w 2006 r., Grzegorz Gazda, wydając (w redakcyjnej współpracy ze Słowinią Tynecką-Makowską) liczący ponad 600 haseł Stownik rodzajów i gatunków literackich (2006). Tak oto to, co mogło skończyć się klęską, nie tylko było, ale i ,jest w ciągłym rozwoju [...], osiąga trudne — bo pozornie nieosiągalne - zwycięstwo" (Skwarczyńska 1985: 281).

\section{IRENA HÜBNER}

iD https://orcid.org/0000-0001-5738-1578

Katedra Teorii Literatury Instytutu Kultury Wspólczesnej Uniwersytetu Łódzkiego, ul. Pomorska 171/173, 90-236 Łódź

e-mail: irena.hibner@uni.lodz.pl 


\section{Bibliografia}

Gazda Grzegorz (1992), Stefania Skwarczyńska jako wydawca i redaktor [w:] Stefania Skwarczyńska. Uczony, nauczyciel, wychowawca, red. Bielacki M., Trzynadlowski J., Wydawnictwo UŁ, Łódź.

- (2006), O Stowniku rodzajów i gatunków literackich [w:] Stownik rodzajów i gatunków literackich, red. Gazda G., Tynecka-Makowska S., Universitas, Kraków.

Ostrowski Witold (1992), „Stownik rodzajów literackich” w zamierzeniu Stefanii Skwarczyńskiej i w realizacji [w:] Stefania Skwarczyńska. Uczony, nauczyciel, wychowawca, red. Bielacki M., Trzynadlowski J., Wydawnictwo UŁ, Łódź.

Skwarczyńska Stefania (1947), Projekt Stownika rodzajów literackich, „Sprawozdania z Czynności i Posiedzeń Łódzkiego Towarzystwa Naukowego", R. 2, nr 1.

- (1985), Eódzki pótrocznik międzynarodowy „Zagadnienia rodzajów literackich - Woprosy literaturnych żanrow - Les problèmes des genres littèraires" (idee i historia) [w:] W orbicie literatury, teatru, kultury naukowej, Instytut Wydawniczy PAX, Warszawa.

Stownik rodzajów i gatunków literackich (2006), red. Gazda G., Tynecka-Makowska S., Universitas, Kraków.

Stefania Skwarczyńska. Uczony, nauczyciel, wychowawca (1992), red. Bielacki M., Trzynadlowski J., Wydawnictwo UŁ, Łódź. 